\title{
Interactive comment on "Learning about precipitation orographic enhancement from snow-course data improves water-balance modeling" by Francesco Avanzi et al.
}

\section{Francesco Avanzi et al.}

francesco.avanzi@cimafoundation.org

Received and published: 2 February 2021

We thanks Reviewer \#1 for their constructive comments. We confirm that all requested revisions are feasible and we will work in this direction as soon as the interactive discussion will be finalized. Please find a detailed point-by-point reply to all comments attached.

Please also note the supplement to this comment: supplement.pdf 
Interactive comment on Hydrol. Earth Syst. Sci. Discuss., https://doi.org/10.5194/hess-2020571, 2020.

Interactive

comment 